\title{
MID-TERM ABORTION INDUCED IN SHEEP BY SYNTHETIC CORTICOIDS
}

\author{
P. FYLLING, Ø. V. SJAASTAD AND W. VELLE \\ Department of Physiology, Veterinary College of Norway, \\ Oslo, Norway
}

(Received 4th September 1972)

Premature parturition in sheep following administration of synthetic corticoids is now well documented (Van Rensburg, 1967; Bosc, 1970; Skinner, van Blom, Gouws \& Jöchle, 1970; Fylling, 1971). In the cow, both premature parturition (Adams, 1969; Hansen \& Christiansen, 1971 ; Karg, Böhm, Günzler \& Müller, 1971 ; L. E. Edquist, personal communication) and mid-term abortion (L. E. Edquist, personal communication) have been reported following such treatment. Induction of abortion in sheep by synthetic corticoids has not been reported so far. This paper presents a study on the effect of dexamethasone given to ewes during mid-term pregnancy.

Five ewes of the Dala breed, all 80 days pregnant, were included in the investigation. The mean gestational period in this breed is 148 days. The animals received intramuscular injections of $2.5 \mathrm{mg}$ dexamethasone four times

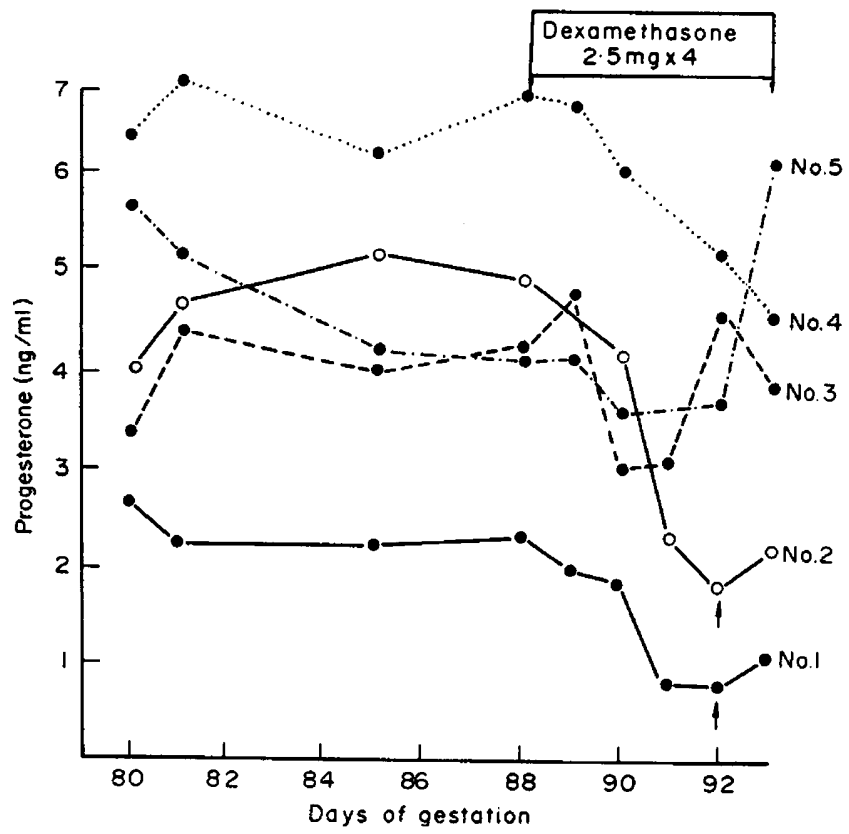

Text-pig. 1. Plasma progesterone levels of peripheral blood in five ewes (Nos 1 to 5 ) injected with $2.5 \mathrm{mg}$ dexamethasone four times daily for 5 consecutive days, starting on Day 88 of pregnancy. The time of abortion is indicated by arrows. 
daily (Decadron', 'MSD') for 5 consecutive days, starting on Day 88 of pregnancy. Blood samples from the jugular vein were drawn at about 09.00 hours every day. The progesterone measurements were performed by the rapid competitive protein-binding technique described previously (Fylling, 1970).

Two of the ewes (Nos 1 and 2) aborted following dexamethasone treatment (Text-fig. 1). A gradual decrease in the plasma progesterone levels towards the time of abortion was observed in both animals. In the other ewes, administration of dexamethasone also seemed to lower the progesterone levels, though the plasma progesterone never reached as low levels as in the ewes that aborted. In Ewe 3, neither abortion nor parturition was observed. Since the progesterone values obtained indicated that the ewe was pregnant, the fetus had probably been resorbed in utero. Ewe 5 gave birth to one living lamb of half the normal birth weight on Day 145 and Ewe 4 produced living twins on Day 148. The twins were also about half the normal birth weight for this breed.

The dose used (10 mg/day) in this investigation has been shown to be sufficient for inducing premature parturition in sheep (Fylling, 1971) and the present results indicate that, in general, higher doses are needed to induce midterm abortion than to induce premature parturition. The low weights of the lambs spontaneously produced by Ewes 4 and 5 recall the situation seen in cases of placental insufficiency in human pregnancy. This apparent effect of dexamethasone given temporarily to sheep during sustained early pregnancy is difficult to explain.

\section{REFERENCES}

Adams, W. M. (1969) The elective induction of labor and parturition in cattle. J. Am. vet. med. Ass. 154, 261.

Bosc, M. J. (1970) Etude de l'induction de la parturition chez la brebis par un corticostéroïde de synthèse, le fluoromethyl prednisolone. C. r. hebd. Séanc. Acad. Sci., Paris, $270,3127$.

Fyluing, P. (1970) The effect of pregnancy, ovariectomy and parturition on plasma progesterone level in sheep. Acta endocr., Copenh. 65, 273.

Fylling, P. (1971) Premature parturition following dexamethasone administration to pregnant ewes. Acta endocr., Copenh. 66, 289.

Hansen, L. H. \& Ghristiansen, I. J. (1971) Undersøkelse av den fødselsstimulerende virkning hos kveg af et corticosteroid (dexamethason). Nord. VetMed. 23, 162.

KARG, H., BöHM, S., GüNZLER, O. \& MülLER, S. (1971) Erfahrungen über die Geburtseinleitung beim Rind mit Glukortikoiden. Dt. tierärztl. Wschr. 78, 35.

Skinner, J. D., van Blom, A., Gouws, D.J. \& Jöchle, W. (1970) The effect of shortening gestation length with flumethasone on pelt quality of Karakul lambs. Proc. S. Afr. Soc. Anim. Prod. 9, 193.

VAN RENSBURG, S. J. (1967) Gestation in sheep after foetal adrenalectomy and cortisol acetate administration. F. Endocr. 38, 83. 